\title{
The Effect of Working Capital Management on Profitability: Evidence from Malaysian Construction Firms
}

\author{
You Chooi Yin, Teo Yuen Lee, Yong Man Ning, Crispina Ayang anak Jimbai, and Chong \\ Chui Wen \\ Faculty of Economics and Business, Universiti Malaysia Sarawak
}

\begin{abstract}
Working capital management is an essential part of a sound business. The main objective of this research is to investigate the effect of working capital management on profitability. The regression analysis was carried out on a panel sample of 30 construction firms listed on Bursa Malaysia over a fiveyear period from 2015 to 2019. The findings suggest that there is a significant positive relationship between Days Inventory Outstanding (DIO) and Gross Operating Profit (GOP) as well as a significant negative relationship between Days Payables Outstanding (DPO) and GOP. Thus, firms can maximise their profitability by maintaining higher inventory level and paying off creditors in a shorter time frame.
\end{abstract}

\section{INTRODUCTION}

Every business requires working capital for its survival. Working capital is a vital part of business investment which is essential for continuous business operations. It is required by a firm to maintain its liquidity, solvency and profitability (Lazaridis \& Tryfonidis, 2006). Working capital management explicitly impacts both the profitability and level of desired liquidity of a business. Hence, it may have both negative and positive impact on firm's profitability, which in turn, has negative and positive impact on the shareholders' wealth (Raheman \& Nasr, 2007). If a firm invests heavily on working capital more than its needs, the profits which can be generated by investing these resources in fixed or long-term assets diminishes. Moreover, the firm have to endure the cost of storing inventory for longer periods as well as the cost of handling excessive inventory (Arnold, 2008). It is therefore a critical issue to know and understand the effects of working capital management and its influence on the probability of firm. A popular measure of working capital management is the cash conversion cycle (CCC). It is the time lag between the expenditure for the purchases of raw materials and the collection of sales of finished goods. The longer the time lag, the larger the investment in working capital. A longer CCC might increase profitability as it leads to higher sales. On the other hand, it might reduce the corporate profitability, given that the benefits of holding more inventory or granting more trade credit to customers could not cover the costs of higher investment in working capital. The problem encountered here is, whether working capital management has positive or negative relationship with a company's profitability? Accounting and Finance literature argues that working capital management is negatively associated with a firm's profitability (Lazaridis \& Tryfonidis, 2006; Rehman, 2006; Öz \& Güngör, 2007; Gill, et al., 2010; Anser \& Malik, 2013). These results coincide with the cash conversion cycle theory where it is stated that a shorter cash conversion cycle indicates that the firm is healthier and is generating higher profit. 
Meanwhile, research by Çakır (2013) mentioned that the working capital management, measured by CCC is positively related to the profitability. Shin and Soenen (1998) also argued that firm can have larger sales with a generous credit policy, which extends the cash cycle. In this case, the longer cash conversion cycle may result in higher profitability. However, the traditional view of the relationship between the cash conversion cycle and firms' profitability is that, ceteris paribus, a longer cash conversion cycle affect the profitability of a firm negatively. Building on these theoretical assumptions, is it true that the working capital management has a negative relationship with profitability? Previous studies into the relationship between working capital management and profitability has highlighted on the influence of optimal inventory management, optimal accounts receivable and payable, and the cash conversion cycle on a firm's profitability (Deloof 2003; Padachi 2006; Lazaridiz \& Tryfonidis 2006; Garcia-Teruel \& Solano 2007; Gill, Biger, \& Mathur 2011; Baños-Caballero et al. 2012). Furthermore, other researchers have analysed the association between working capital management and financial access (Ding Guariglia \& Knight 2013), as well as the effect of working capital on profit. (Enqvist et al. 2014). Some of the results were consistent, while others were mixed; even so, the key finding that has been widely recognized is that working capital management has a huge effect on a firm's profitability.

The efficiency of working capital management is particularly crucial for construction companies, where current assets make up the majority of assets. It has a significant impact on a company's profitability and liquidity (Raheman \& Nasr, 2007). In Malaysia, construction sector is growing as the government attempts to put the country's infrastructure up to par with that of other developed and emerging countries. In the construction sector, significant investments are being made particularly in infrastructure, industrial parks and residential buidlings. Nai-Chiek and Peck-Ling (2019) stated that under the 11th Malaysia Plan (11MP), which runs from 2016 to 2020, Malaysia's major infrastructure projects are anticipated to boost the construction industry and other downstream industries. The High Speed Rail, Pan Borneo Highway, East Coast Rail Link, Bandar Malaysia, and Vision Valley are among the projects that are expected to improve the economy by more than $50 \%$ to RM2 trillion by the end of $11 \mathrm{MP}$ (Nai-Chiek \& Peck-Ling, 2019). During the period of 2015 to 2019, the residential construction industry grew at a compound annual growth rate (CAGR) of $8.92 \%$ in value terms. According to Mohd Uzir Mahadin (2019), the performance of construction sector recorded value of gross output RM204.4 billion in 2017 compared to RM177.9 billion in 2015 with an annual growth rate of $7.2 \%$ per annum. Studies on working capital management and profitability have been conducted extensively in affluent countries. However, work on capital management in developing countries has been sparse. As a result, the same methodology as in the earlier studies of Deloof (2003), Lazaridis and Tryfonidis (2006), Padachi (2006), Garcia-Teruel and Solano (2007), and Caballero et al. (2012) which entails conducting an in-depth and thorough analysis of working capital management and profitability is adopted in this research to validate the factors of Malaysian construction firm's profitability in terms of capital management. Hence, the objective of this study is to investigate the effect of working capital management on profitability of listed construction firms in Malaysia.

Our findings suggest that listed construction firms in Malaysia can increase their profitability by retaining greater inventory level and paying off their creditors in a shorter time frame. These findings may provide construction firm owner-managers with ideas for more efficient capital management, and will fill the gap of the literature on working capital management in construction firms. Based on previous researches and theoretical assumptions, working capital management would impact firms' profitability and liquidity be it small or large companies and construction companies should have no exception. Hence, to further verify these assumptions, this study focuses to examine the effect of working capital 
management on the profitability of construction companies in Malaysia which are listed under Bursa Malaysia over a 5-year period from the year 2015 to 2019. The study is organised as follows. Section 2 provides brief review of significant theoretical and empirical literature on the effects of working capital management on firm's profitability, the third section shows the research methodology whereas the fourth section comprises of empirical results. As for the fifth sections, discussion of data analysis and findings of the study are presented. Then, the sixth section which is the last one consists of conclusion and recommendations respectively.

\section{LITERATURE REVIEW}

Major corporations have a large portion of their finance workers dealing with day-to-day problems regarding working capital decision-making. Commonly, working capital management (WCM) is referred to the difference between current assets and current liabilities of a firm (Park \& Gladson, 1963). In terms of elements, WCM consists of inventory management, account receivable, account payable and cash conversion cycle. It is a crucial part of financial management (Deloof, 2013). The WCM can have a great effect on a company's profitability and liquidity (Lazaridis \& Tryfonidis 2006). An effective WCM entails managing and regulating current assets and liabilities in a way that reduces the possibility of being unable to fulfill short-term debt on one hand, while prevents unnecessary expenditure in assets on the other hand (Eljelly, 2004). Good working capital management is essential since a company that cannot settle its payments is actually insolvent. As an example, the amount of current assets is high as compared to total assets for trade and manufacturing companies, therefore working capital must be handled optimally, balancing liquidity and profitability. Even a company is effective, if significant amounts are locked up in receivables accounts, the company would have to loan more or take more debt to cover the stock. Thus, this might cause a situation that the company needs money to purchase inventory for sales and would suffer an expense if the outstanding balance is used to fund stocks. As a result, if the company wants to operate efficiently, the liquidity and profitability of the company must be properly managed (Padachi, 2006).

\section{Empirical Evidence}

Previous studies have shown that working capital management has an effect on a company's profitability. The effective working capital management is one of the important features of financially profitable firms (Johnson \& Soenen, 2003). The majority of research concluded that there is a negative relation between WCM and profitability (Deloof, 2003; Arbidane \& Ignatjeva, 2012; Ebrahim Mansoori \& Joriah Muhammad, 2012; Lazaridis \& Tryfonidis, 2006; Thuvarakan, 2013; Tran, Abbott \& Yap, 2017; Aregeyen, 2013; Botoc \& Anton, 2017; Napompech, 2012). This indicated that lowering current assets as a percentage of total assets lowers working capital investment, which has a positive impact on the profitability of the firm. However, some research founded that the correlation between WCM and profitability is positive (Kwatiah \& Asiamah, 2020; Sharma \& Kumar, 2011). The cash conversion cycle has been used as the proxy of working capital in most of the research. Deloof (2003) studied the impact of working capital management on the profitability of Belgian firms. A sample of 1009 firms for the period from 1992 to 1996 has been collected to carry out this research. The results indicated that there is a negative relation between working capital management and profitability. This implied that the firms can increase their profitability by shortening the number of days accounts receivable and inventories. He also mentioned that poorer companies would take more time to meet their obligations. 
Besides, Lazaridis and Tryfonidis (2006) examined the relationship between working capital management and profitability of Athens Stock Exchange firms by using a sample of 131 firms for the period of 2001 to 2004. Their result showed that profitability is negatively associated with the cash conversion cycle. They presented that managers can gain benefits for their firms by properly managing the cash conversion cycle and maintaining each element such as accounts receivables, accounts payables and inventory at an optimum level. In addition, Arbidane and Ignatjeva (2013) selected 165 Latvian firms covering a period of 2004 to 2010 to examine the relationship between working capital management and profitability. They used multifactor analysis in their research. They concluded that return on assets is significantly negatively correlated with receivables collection period while it is less significant between gross operating profit and receivables collection period. Apart from that, Ebrahim Mansoori and Joriah Muhammad (2012) in their research selected 92 Singapore firms for a period of 2004 to 2011. The research used OLS regression and fixed analysis regression. The result showed that the receivable conversion period, inventory conversion period and payable deferral period have a negative relationship with return on assets. Furthermore, Thuvarakan (2013) investigated the influence of working capital management on the profitability of selected 485 manufacturing firms in UK with a 6-year period from 2006 to 2011 . Pooled ordinary least square method and generalized least square method were used in the study. This study's findings indicate that probability has no significant relationship with receivable days, payable days, inventory days and cash conversion cycle.

Based on the study by Tran, Abbott and Yap (2017), a research on the effect of WCM on profitability was carried out on a sample covering 200 Vietnamese SMEs for a period over 2010 to 2012. The result demonstrated that there is a significant negative correlation between gross operating profit and the number of days of accounts receivable, accounts inventories, and cash conversion cycle. They argued that SMEs firms can increase their profitability by decreasing the period of the cash conversion cycle. Other than that, Kwatiah and Asiamah (2020) analyzed 20 manufacturing firms in Ghana from 2015 to 2019 and evaluate the data using the fixed effects model. The research implied that the accounts receivables, inventory management, accounts payable and cash conversion cycle have impacted the ROA and ROE positively. Sharma and Kumar (2011) studied 263 non-financial listed firms in India. They used OLS multiple regression in their research. The findings of the study also reveal that profitability has a positive impact on working capital management. The study further stated that the number of days of inventory and number of days of account payable have an inverse relationship with profitability whereas the number of days accounts receivables and cash conversion period are positively correlated with profitability.

Moreover, Aregbeyen (2013) conducted a study on the influence of working capital management on the manufacturing firms' profitability in Nigeria. A sample of 48 firms from 1993 to 2005 was selected in the study. The data was analyzed using OLS regression. The result indicated that working capital management is negatively related to the profitability. Another research was conducted on a sample of 255 Thai listed firms by Napompech (2012) over the year from 2007 to 2009. The findings showed that gross operating profits are significantly negatively correlated to inventory conversion period and receivables collection period. The study also demonstrated that payables deferral period has an insignificant inverse relationship with profitability. Last but not least, the research by Botoc and Anton (2017) helps to determine the correlation between working capital management and profitability. They employed a sample of 937 firms from 2006 to 2015 and evaluate the data using GMM system model and quantile regression. The study found that there is a concave relationship between working capital management and profitability 
They concluded that working capital management needs to be refocused, particularly for fast-growing firms.

\section{Theoretical Review}

There are several theories relevant to the management of working capital. In this study, the pecking order theory, cash conversion theory and agency theory will be discussed.

\section{Pecking order theory}

Pecking order theory is based on information asymmetry, in which companies' managers are thought to know more about the company's values than prospective investors. The pecking order theory states that financing needs that cannot be fulfilled by internally generated funds will be obtained from external capital markets (Myers \& Majluf, 1984). Internal funds are believed to have no costs and the use of debt indicates optimistic information, whereas the use of common stock indicates unfavourable information of the firm. Hence, the pecking order encourages companies to keep sufficient cash on hands and most liquid assets in order to assure that the debts are fulfilled as they arise and the external funds are not being used (Chen, 2004). Besides, the theory also stated that when a firm uses a conventional funding approach, it has better access to loans and is considered more stable by potential investors (Kwatiah \& Asiamah, 2020). Accordingly, firms should implement an aggressive working capital strategy with lower assets and higher supplier funding. This would probably guarantee a sufficient amount of internal funds to support the firm's operations without preferably resorting to debt to equity. Clearly, the pecking order theory is applicable when it comes to the working capital management in firms that operate in extremely unstable economic conditions. Moreover, this theory also useful in understanding the inconsistency of knowledge between management and investors, and it offers a way of addressing some of the shortcomings of the firm's original capital structure view.

\section{Cash Conversion Cycle (CCC) theory}

According to Richards and Laughlin (1980), cash conversion cycle theory describes how companies can minimize the consequences of bad working capital management by maintaining a shorter operations cycle. It measures the period of time between a firm's purchases of stocks and receives money from its debtors. Managers can use this theory to estimate how long a company's cash will be tied up in its activities. Kabuye, Kato, Akugizibwe and Bugambiro (2019) stated that the CCC is prolonged when the firm takes a long time to collects the unpaid accounts receivables, carries a large amount of inventory, or settles its payment too fast. In other words, a longer CCC indicates the company is insolvent as it needs a longer time to make money. In contrast, when a company takes a shorter period of time to collects its outstanding accounts receivables, sells the inventory quickly, or settles the payment slowly, the CCC is reduced. Eventually, a lower CCC reflects a healthy company. It can be concluded that CCC theory is the main theory that describes the management of working capital in context of all concepts and elements, which includes the inventory conversion period, receivables collection period, payment deferral period as well as cash component. Apart from that, Oseifuah and Gyekye (2016) mentioned that ceteris paribus, 
efficient working capital management will enhance the liquidity and profitability of a firm, whereas ineffective working capital management will result in reduced profitability and firm value.

\section{Agency theory}

Agency theory describes the relationship and contracts that exist in a company among the stakeholders and the managers (Jensen \& Meckling, 1976). Managers are required to pursue the shareholders' interests. Nevertheless, they are unable to accomplish them because of the manager's irrational opportunistic behaviour, which causes agency disputes or issues (Jensen, 1994). This theory is significant in the firms' financial management since it is based on the capabilities and morals of the managers in charge of leading the company. It is essential in working capital management, particularly for organizations that functioning in an extremely volatile and unpredictable environment as large agency costs are spent in guaranteeing the achievement and sustainability of organization. Besides, this theory is useful when dealing with the element of WCM. It helps to illustrates why debt is employed as a form of funding even when the advantages of a tax are not available. Modigliani and Miller (1963) reported that the company's structure is irrelevant in an environment that lacks of tax advantages. However, Jensen and Meckling (1976) mentioned that a company's optimum ownership structure is determined by a trade-off between agency costs of debt and equity. This indicated that why debt is a preferred way of funding even there are no tax advantages. Moreover, it is reasonable to argue that agency theory strikes at the core of the establishment of corporate governance stream. It also reveals why there is a chance that maximum value will not be created when management is extremely effective.

\section{RESEARCH METHODOLOGY}

The data employed in this study is panel data and data included are yearly data on sales, cost of goods sold, total assets, financial assets, financial liabilities, account receivables, inventories, accounts payables, days sales outstanding (DSO), days inventory outstanding (DIO), days payable outstanding (DPO), cash conversion cycle (CCC), firm size (SIZE), sales growth (GROWTH) and leverage (LEV). In this research, the area of study is focused on the construction industry in Malaysia for the period of 2015 to 2019. All construction companies listed on Bursa Malaysia during this period are included in the initial sample. Then, companies with missing data to compute the independent variables or control variables are excluded. This results in 30 companies in the final sample which amounts to 150 observations. The data used in this study is sourced from Bursa Malaysia and the annual report of each company. Descriptive analysis, Pearson correlation analysis, Pooled Ordinary Least Square (POLS) regression analysis, Fixed Effect (FE) regression analysis and Random Effect (RE) regression analysis are carried out on the model to obtain a clear view of the model as well as examine the relationship between the independent variables and dependent variables. Descriptive statistics shows the mean, median, maximum and minimum value as well as standard deviation of all variables included in this study. Besides, Pearson correlation analysis is adopted to investigate the relationship between the variables used in this study. Moreover, in order to study the effect of CCC and its components (DSO, DIO, DPO) on a firm's profitability, DSO, DIO and DPO are regressed against GOP using POLS regression, FE regression and RE regression.

The dependent variable used in this study is profitability, which is measured by GOP. GOP can be calculated by deducting cost of goods sold from sales and then divided by total assets minus financial 
assets. The adoption of GOP as a measurement for profitability coincides with the researches by Deloof (2003); Lazaridis and Tryfonidis (2006); Thuvarakan (2013); Tran, Abbott and Yap (2017); Sharma and Kumar (2011); Aregbeyen (2013); Botoc and Anton (2017) and Napompech (2012). GOP is employed in this study instead of return on equity (ROE), return on assets (ROA) and earnings before interest tax depreciation amortization (EBITDA) because GOP is more relatable to CCC and its components.

In line with previous studies by Deloof (2003); Lazaridis and Tryfonidis (2006); Thuvarakan (2013); Tran, Abbott and Yap (2017); Sharma and Kumar (2011); Aregbeyen (2013); Botoc and Anton (2017) and Napompech (2012), CCC is used as a measure for working capital management. CCC is obtained by deducting DPO from the sum of DSO and DIO. CCC refers to the period taken by firms to convert its inventories into cash flow from sales (Napompech, 2012). A shorter period of CCC is preferable because it reflects less amount of current assets to cash and also implies high liquidity, which allows the current assets to be easily converted to cash. Meanwhile, a longer period of CCC implies a greater amount of current assets and thereby signals the greater need for current assets financing (Sharma and Kumar, 2011). Besides, the three components of CCC which include DSO, DIO and DPO were also employed as independent variables in the study. DSO is calculated by the accounts receivable divided by sales and then multiplied by 365 . DIO is calculated by the inventories divided by cost of goods sold and then multiplied by 365 while DPO is calculated by accounts payable divided by cost of goods sold and then multiplied with 365. A longer period of inventory held and the receivable collection, as well as a shorter period for payment to a firm's creditor, indicate that cash is being retained in inventory and the receivables and used more rapidly to pay off trade payables (Napompech, 2012). This would probably decrease the available cash of the firm. Thus, the firm needs to shorten the CCC in order to lower its financial needs. It can be conducted by shortening the inventory conversion period, increasing the speed of the receivable collection, and delaying payments to creditors. Accordingly, CCC, DSO, DIO and DPO were used in this study to examine whether a significant positive or negative relationship exists between these variables and firm profitability.

With regard to control variables, firm size (SIZE), sales growth (GROWTH) and leverage (LEV) were included in the regression analysis. The firm size is measured through the natural logarithm of sales, while the sales growth is calculated by deducting previous year's sales from this year's sales and then divided by previous year's sales. The sales growth indicates the development of the natural business. As for leverage, it is a ratio of financial debt divided by total assets, which demonstrates the financial access of the firm (Tran, Abbott \& Yap, 2017). These control variables also have been used in previous studies such as studies by Thuvarakan (2013), Ebrahim Mansoori and Joriah Muhammad (2012), Arbidane and Ignatjeva (2013), Napompech (2012), Tran, Abbott and Yap (2017), Kwatiah and Asiamah (2020), and Sharma and Kumar (2011) and Botoc and Anton (2017). The measurements and formulas for the respective variables are shown in the table below.

In this study, the estimated econometric model is listed as:

$$
\begin{gathered}
\text { Profitability (GPO })_{\mathrm{it}}=\alpha+\beta_{1}(\mathrm{DSO})_{\mathrm{it}}+\beta_{2}(\mathrm{DIO})_{\mathrm{it}}+\beta_{3}(\mathrm{DPO})_{\mathrm{it}}+\beta_{4}(\mathrm{CCC})_{\mathrm{it}}+\beta_{5}(\mathrm{SIZE})_{\mathrm{it}}+ \\
\beta_{6}(\mathrm{GROWTH})_{\mathrm{it}}+\beta_{7} \mathrm{LEV}_{\mathrm{it}}+\mu_{\mathrm{it}}
\end{gathered}
$$


Table 1: Measurement and Formula of Dependent Variable, Independent Variables and Control Variables

\begin{tabular}{|c|c|}
\hline Variable & Formula \\
\hline \multicolumn{2}{|l|}{ Dependent variable } \\
\hline Gross operating profit (GOP) & $\begin{array}{l}\text { (Sales-Cost of goods sold) / (Total assets/Financial } \\
\text { assets) }\end{array}$ \\
\hline \multicolumn{2}{|l|}{ Independent variables } \\
\hline Days Sales Outstanding (DSO) & (Accounts receivable/ Sales) $* 365$ \\
\hline Days Inventory Outstanding (DIO) & (Inventories/ Cost of goods sold) $* 365$ \\
\hline Days Payable Outstanding (DPO) & (Accounts payable/ Cost of goods sold)*365 \\
\hline Cash Conversion Cycle (CCC) & $\mathrm{DSO}+\mathrm{DIO}$ - DPO \\
\hline \multicolumn{2}{|l|}{ Control variables } \\
\hline Firm Size (SIZE) & $\log$ (sales) \\
\hline Sales growth (GROWTH) & $\begin{array}{l}\text { (This year's sales-Previous year's year)/ Previous year's } \\
\text { sales }\end{array}$ \\
\hline Leverage (LEV) & Financial debt/Total assets \\
\hline
\end{tabular}

\section{EMPIRICAL RESULTS}

Table 2: Descriptive Statistics

\begin{tabular}{|l|c|c|c|c|c|}
\hline \multicolumn{1}{|c|}{ Variables } & Observation & Mean & Minimum & Maximum & $\begin{array}{c}\text { Standard } \\
\text { Deviation }\end{array}$ \\
\hline $\begin{array}{l}\text { Profitability } \\
\text { (gross operating } \\
\text { profit) }\end{array}$ & 150 & 0.188 & -0.457 & 1.116 & 0.211 \\
\hline $\begin{array}{l}\text { Days Sales } \\
\text { Outstanding } \\
\text { (DSO) }\end{array}$ & 150 & 196 & 32 & 1703 & 185 \\
\hline $\begin{array}{l}\text { Days Inventory } \\
\text { Outstanding } \\
\text { (DIO) }\end{array}$ & 150 & 226 & 0.061 & 5707 & 705 \\
\hline $\begin{array}{l}\text { Days Payable } \\
\text { Outstanding } \\
\text { (DPO) }\end{array}$ & 150 & 335 & 27 & 5916 & 665 \\
\hline $\begin{array}{l}\text { Cash } \\
\text { Conversion } \\
\text { Cycle (CCC) }\end{array}$ & 150 & 93 & -1466 & 1942 & 338 \\
\hline Firm Size & 150 & 8.613 & 7.391 & 9.916 & 0.487 \\
\hline Sales Growth & 150 & 0.122 & -0.919 & 6.485 & 0.723 \\
\hline Leverage & 150 & 0.543 & -0.421 & 2.666 & 0.474 \\
\hline
\end{tabular}


Table 2 shows the descriptive statistics of all the variables. The data includes mean, standard deviation, minimum and maximum value for respective variable. The total number of observations are 150 . The mean value of GOP is $18.8 \%$ and the standard deviation is $21.1 \%$. This means that GOP can deviate from the mean to the both sides by $21.1 \%$. The median value of GOP is 0.122 . Besides, DSO has an average of 196 days and standard deviation of DSO recorded as 185 days. The maximum amount of time period for companies to collect receivables from customers is 1703 days and a minimum time is 32 days. Furthermore, the average of DIO is 226 days and it fluctuates in the range from 0.061 to 5707 days. On average, companies take 335 days to make their payment to the suppliers. The maximum period is 5916 days and the minimum period is 27 days. Apart from that, $\mathrm{CCC}$ has an average value of 93 days with the lowest value of -1466 days and the highest value of 1942 days. A standard deviation of 338 days is recorded by CCC. As for firm size, firm's sales growth and leverage, the mean values are 8.613, 0.122 and 0.543, and the standard deviations are $0.487,0.723$ and 0.474 with maximum values of $9.916,6.485$ and 2.666 and minimum value of $7.391,-0.919$ and -0.421 respectively.

\section{Correlation Analysis}

Table 3: Pearson Correlation Coefficients of Working Capital Management and Profitability

\begin{tabular}{|c|c|c|c|c|c|c|c|c|}
\hline Variables & GOP & DSO & DIO & DPO & $\mathrm{CCC}$ & $\begin{array}{r}\text { FIRM } \\
\text { SIZE }\end{array}$ & $\begin{array}{r}\text { SALES } \\
\text { GROWTH }\end{array}$ & LEVERAGE \\
\hline GOP & 1 & & & & & & & \\
\hline DSO & $\begin{array}{r}-0.2051 \\
0.0118\end{array}$ & 1 & & & & & & \\
\hline DIO & $\begin{array}{l}0.1944 \\
0.0171\end{array}$ & $\begin{array}{l}0.0408 \\
0.6202\end{array}$ & 1 & & & & & \\
\hline DPO & $\begin{array}{l}0.1715 \\
0.0359\end{array}$ & $\begin{array}{l}0.0451 \\
0.5834\end{array}$ & $\begin{array}{l}0.9150 \\
0.0000\end{array}$ & 1 & & & & \\
\hline $\mathrm{CCC}$ & $\begin{array}{r}-0.0524 \\
0.5243\end{array}$ & $\begin{array}{l}0.5509 \\
0.0000\end{array}$ & $\begin{array}{l}0.3029 \\
0.0002\end{array}$ & $\begin{array}{r}-0.0337 \\
0.6820\end{array}$ & 1 & & & \\
\hline FIRM SIZE & $\begin{array}{r}-0.0129 \\
0.8752\end{array}$ & $\begin{array}{r}-0.3409 \\
0.0000\end{array}$ & $\begin{array}{r}-0.1406 \\
0.0861\end{array}$ & $\begin{array}{r}-0.1328 \\
0.1052\end{array}$ & $\begin{array}{r}-0.2077 \\
0.0107\end{array}$ & 1 & & \\
\hline $\begin{array}{l}\text { SALES } \\
\text { GROWTH }\end{array}$ & $\begin{array}{l}0.0611 \\
0.4577\end{array}$ & $\begin{array}{r}-0.1214 \\
0.1390\end{array}$ & $\begin{array}{r}-0.0630 \\
0.4441\end{array}$ & $\begin{array}{r}-0.0453 \\
0.5822\end{array}$ & $\begin{array}{r}-0.1059 \\
0.1973\end{array}$ & $\begin{array}{l}0.0063 \\
0.9392\end{array}$ & 1 & \\
\hline LEVERAGE & $\begin{array}{r}-0.0848 \\
0.3021 \\
\end{array}$ & $\begin{array}{r}-0.0122 \\
0.8818 \\
\end{array}$ & $\begin{array}{r}-0.1813 \\
0.0264\end{array}$ & $\begin{array}{r}-0.2030 \\
0.0127 \\
\end{array}$ & $\begin{array}{l}0.0173 \\
0.8337\end{array}$ & $\begin{array}{l}0.0204 \\
0.8039\end{array}$ & $\begin{array}{r}-0.0269 \\
0.7439 \\
\end{array}$ & 1 \\
\hline
\end{tabular}

Table 3 presents Pearson correlation coefficients for all variables in this study. As shown in the table above, the coefficient between gross operating profit (GOP) and days sales outstanding (DSO) is 0.2051 and the p-value (0.0118) is significant at 0.05 level. This implies that there is a significant negative 
relationship between GOP and DSO. This reflect that collecting money from customers faster will increase the profit of the firm. In other words, the shorter the number of days of account receivable, the greater the firm's profitability. The coefficient value between GOP and days inventory outstanding (DIO) is 0.1944 while the value between GOP and days payable outstanding (DPO) is 0.1715 , which indicates that both DIO and DPO have positive correlation with GOP. Besides, both the p-value of GOP and DIO (0.0171) and GOP and DPO (0.0359) are less than the significance level of 0.05. This demonstrates that DIO and DPO are significantly positively correlated with GOP. To further elaborate, invest more in inventory and delay the period to clear off the outstanding payment will result in an increase in the firms' profitability.

With regards to correlation between GOP and cash conversion cycle (CCC), the coefficient value is -0.0524 . The coefficient value between GOP and firm size also recorded a negative value of -0.0129 . In other words, a negative relationship exists between these variables. The p-value of correlation between GOP and CCC (0.5243) and GOP and firm size (0.8752) are both greater than 5\% significance level. This shows that the association between these variables are not statistically significant. The positive sign of correlation value of GROWTH (0.0611) means that an increase in sales growth would leads to an increase in GOP. The p-value of 0.4577 is greater than 5\% significance level and this indicates that the correlation between GROWTH and GOP is not statistically significant. Other than that, a negative relationship also exists between leverage and GOP as the correlation value is -0.0848 . The p-value $(0.3021)$ is greater than the significance value of 0.05 . This result indicates that the relationship between leverage and GOP is not statistically significant. Overall, the correlation values of dependent variable, independent variables and dependent variables are less than 0.8 except for DPO and DIO which shows a value greater than 0.8 (0.9150). This stipulates that multicollinearity exists between DPO and DIO.

\section{Pooled Ordinary Least Square (OLS) Model, Fixed Effect Model (FEM) Random Effect Model (REM)}

This section presents the results of Pooled Ordinary Least Square (OLS) model, estimated Fixed Effect Model (FEM) and Random Effect Model (REM). Breusch-Pagan Lagrangian Multiplier (LM) Test is used to distinguish between Pooled OLS and Random Effect Model in order to evaluate which regression model is more precise for the dataset. Based on the results of Breusch-Pagan LM test, the probability is less than 0.05 significance level and the null hypothesis of no random effect is rejected. There is enough statistical evidence to prove that FEM or REM is appropriate in this study. The Hausman test is applied in the next step to determine the best model. The p-value of Hausman Test is 0.7701, which is greater than the 5\% significance level. Hence, the null hypothesis is not rejected. It can be concluded that the preferred model in this study is REM. REM is more suitable to be used in this study instead of FEM. 
Table 4: Result of Estimated Pooled OLS, Fixed Effect Model (FEM) and Random Effect Model (REM)

\begin{tabular}{|lccc|}
\hline Variables & Pooled OLS & $\begin{array}{c}\text { Fixed Effect (FE) } \\
\text { Model }\end{array}$ & $\begin{array}{c}\text { Random Effect (RE) } \\
\text { Model }\end{array}$ \\
\hline C & 0.4443 & -0.6133 & -0.1520 \\
DSO & $(0.1849)$ & $(0.257)$ & $(0.721)$ \\
& 0.0001 & $-1.31 \times 10^{-5}$ & $5.53 \times 10^{-5}$ \\
DIO & $(0.840)$ & $(0.982)$ & $(0.918)$ \\
& 0.0004 & $6.67 \times 10^{-5}$ & 0.0002 \\
DPO & $(0.439)$ & $(0.908)$ & $(0.706)$ \\
& -0.0004 & $-6.53 \times 10^{-5}$ & -0.0002 \\
CCC & $(0.499)$ & $(0.910)$ & $(0.741)$ \\
& -0.0003 & $-5.81 \times 10^{-5}$ & -0.0002 \\
FIRM SIZE & $(0.512)$ & $(0.920)$ & $(0.725)$ \\
& & 0.0953 & 0.0426 \\
SALES GROWTH & -0.0239 & $(0.123)$ & $(0.378)$ \\
& $(0.526)$ & 0.0188 & 0.0205 \\
LEVERAGE & 0.0137 & $(0.302)$ & $(0.239)$ \\
& $(0.563)$ & -0.0140 & -0.0183 \\
\hline$R^{2}$ & -0.0225 & $(0.561)$ & $(0.437)$ \\
Adjusted $R^{2}$ & $(0.536)$ & 0.0606 & 0.0506 \\
F-statistic & & & \\
Probability value for F- & 0.0947 & 1.04 & \\
statistic & 0.0501 & 0.4067 & 0.3724 \\
Wald Chi2(7) & 2.12 & & \\
P > Chi2 & 0.0449 & & \\
\hline
\end{tabular}

Table 5: Breusch \& Pagan Lagrangian Multiplier (LM) Test

\begin{tabular}{|c|c|c|}
\hline & Chibar2(01) & Prob>Chi2 \\
\hline Breusch-Pagan Test & 108.78 & 0.0000 \\
\hline
\end{tabular}

Table 6: Hausman Test

\begin{tabular}{|c|c|c|}
\hline & Chi2 (7) & Prob>Chi2 \\
\hline Hausman Test & 4.08 & 0.7701 \\
\hline
\end{tabular}

Table 4 illustrates the coefficients of the independent variables and control variables based on FEM and REM. Since REM is determined as the preferred model in this study, the results obtained using REM will be discussed in this part. According to Table 4.3, DSO showed a positive $\left(5.53 \times 10^{-5}\right)$ relationship with GOP. The result shows that an increase in GOP is related with an increase of one day in the number of days of accounts receivable outstanding, which is consistent with the findings of Sharma and Kumar (2011). A high probability will be achieved if there is a high amount of investment in account receivable, while firm profitability is low if they deviate from their high level of trade credit. However, the relationship 
between DSO and GOP is not statistically significant since p-value (0.918) is greater than 0.05 significance level. The coefficient of DIO (0.0002) also has a positive relationship with GOP. This result implies that there is an increase of $0.02 \%$ in GOP following an increase of one day in the number of days inventory outstanding. The finding is consistent with the previous studies by Mathuva (2010). Therefore, firms can achieve higher profitability with higher level of inventories. This matches with the study by Ponsian et. al. (2014), which suggested that the relationship between DIO and GOP should be positive since the firm need plenty of goods in order to maintain the liquidity and profit. However, the p-value of this factor (0.706) is greater than the significance level of 0.05. Hence, the relationship between DIO and GOP is not statistically significant. This finding is consistent with the previous study from Thuvarakan (2013). Thuvarakan (2013) found that there is an insignificant relationship between DIO and GOP. On the other hand, there is a negative relationship between DPO and GOP. A decrease of one day in the number of days payables outstanding lead to an increase of $0.02 \%$ in GOP. According to Deloof (2003), profitability may be increased by receiving a discount for earlier payment if companies accelerated their payment to suppliers. However, the p-value for this factor is 0.741 , implying that the relationship is not significant at the 5\% significance level. The result of this research is consistent with the study carried out by Samiloglu and Akgün (2016). They stated that there is a negative and insignificant relationship between DPO and GOP.

Other than that, the value of coefficient of $\mathrm{CCC}$ is -0.0002 and this indicates that there is a negative relationship between the CCC and GOP. A one-day decrease in the CCC will lead to an increase of $0.02 \%$ in profitability. The probability of CCC is 0.725 , which is greater than 0.05 significance level and it can be concluded that there is no significant relationship between CCC and GOP. It is in line with the research by Shin and Soenen (1998), Deloof (2003) as well as Samiloglu and Akgün (2016). These researched claimed that $\mathrm{CCC}$ has an insignificant negative relationship with profitability. In addition, firm size has a coefficient of 0.0426 and this indicates that firm size has a positive relationship with GOP. This implies that GOP will raise by $4.26 \%$ with a unit increase in firm size. However, the result is not statistically significant at $5 \%$ significance level as the p-value of 0.378 is greater than 0.05 significance level. This finding is consistent with the previous studies by Thuvarkan (2013) and Deloof (2003). They claimed that firm size is positively and insignificantly related to profitability.

As for sales growth, the coefficient is 0.0205 , which shows that it has a positive relationship with GOP. This result indicates that one-unit increase in sales growth will lead to $2.05 \%$ increase in GOP. However, the p-value of sales growth is 0.239 , implying that there is no significant relationship between sales growth and GOP. This is in line with the research by Deloof (2003). He found that there is an insignificant relationship between sales growth and GOP. The coefficient value of leverage is -0.0183 , illustrating that leverage has a negative relationship with GOP. This mean that a one-unit increase in leverage leads to a decrease of $1.83 \%$ in GOP. This is consistent with the previous studies by Deloof (2003) and Ponsian et al. (2014) which imply that profitability decreases when leverage increases. However, the p-value of leverage is 0.437 , which is greater than $5 \%$ significance level. As a result, the relationship between leverage and GOP are not statistically significant. 


\section{Diagnostic Test Results \\ Test for Multicollinearity (Variance Inflation Factor)}

According to Gujarati \& Porter (2009), multicollinearity is defined as the exact or inexact linear relationship between the variables. It is characterised into perfect and imperfect multicollinearity, where perfect multicollinearity exists when two of the variables have exact linear relationship while imperfect multicollinearity occurs when two of the variables have inexact linear relationship. The occurrence of multicollinearity problem is detected by the Variance Inflation Factor (VIF) Test. The results of the VIF Test on the random effect model is as follows:

Table 7: Variance Inflation Factor

\begin{tabular}{|c|c|}
\hline Variables & VIF \\
\hline DIO & 550.41 \\
\hline DPO & 489.46 \\
\hline CCC & 129.07 \\
\hline DSO & 41.64 \\
\hline Firm Size & 1.18 \\
\hline Sales Growth & 1.05 \\
\hline Leverage & 1.02 \\
\hline Mean VIF & $\mathbf{1 7 3 . 4 1}$ \\
\hline
\end{tabular}

Generally, multicollinearity problem exists when the mean VIF is more than 10. According to table 7, the mean VIF for the model is 173.41, which exceeds 10. Therefore, we can conclude that multicollinearity does exist in the model.

\section{Test for Heteroscedasticity (Breusch-Pagan Test)}

According to Brooks (2008), the assumption of Classic Linear Regression Model (CLRM) indicates that the error terms should have same or equal variance, which is known as homoscedasticity. In contrast, if the covariance of error terms is not equal, it is known as heteroscedasticity. In this study, Breusch-Pagan test is used to test for the problem of heteroscedasticity in the model. The null hypothesis for this test is there is no heteroscedasticity. If the probability is lower than $5 \%$ significance level, then null hypothesis is rejected. This implies that the heteroscedasticity problem occurs in the model.

Table 8: Breusch-Pagan Test

\begin{tabular}{|c|c|c|}
\hline & Chibar2(01) & Prob > chibar 2 \\
\hline Heteroscedasticity Test & 108.78 & 0.0000 \\
\hline
\end{tabular}

Based on the table above, the probability of Breusch-Pagan test is 0.0000 , which is lower than the 0.05 level of significance. Thus, it can be concluded that there is presence of heteroscedasticity in the model. 


\section{Test for Autocorrelation (Wooldridge Test)}

The assumption of CLRM states that there should be no autocorrelation between disturbances. In another way, this assumption indicates that the error terms are independent to each other or not correlated to each other. If this assumption is violated, an autocorrelation problem exists in the model. In this study, Wooldridge test will be used to determine the presence of autocorrelation. This test can detect the issue when the variables are known to be autocorrelated. Autocorrelation implies that there is a correlation between the error terms at a different period (Brooks, 2008).

Table 9: Wooldridge Test

\begin{tabular}{|c|c|c|}
\hline & F (1, 29) & Prob > F \\
\hline Wooldridge Test & 7.807 & 0.0091 \\
\hline
\end{tabular}

Based on the table above, the probability of Wooldridge test $(0.0091)$ is lower than the 5\% significance level. Thus, null hypothesis is rejected. This illustrates that the error term exhibits serial correlation problem. In other words, there is autocorrelation issue in the estimated model.

\section{Robustness Check}

In the context of robustness check, the estimation results calculated by STATA solved the issue of diagnostic tests through the robustness standard errors method. The consequences of heteroscedasticity and autocorrelation can be rectified by adding cluster to regression command. After conducting this check, some of the variables became significant as their p-values are less than 5\% significance level.

Table 10: Robustness Results

\begin{tabular}{|c|c|c|c|}
\hline GOP & Coefficient & Robust Std Err & Probability \\
\hline C & 0.4443 & 0.3871 & 0.260 \\
\hline DSO & 0.0001 & 0.0002 & 0.637 \\
\hline DIO & 0.0004 & 0.0002 & 0.012 \\
\hline DPO & -0.0004 & 0.0002 & 0.026 \\
\hline CCC & -0.0004 & 0.0002 & 0.062 \\
\hline FIRM SIZE & -0.0239 & 0.0403 & 0.557 \\
\hline SALES GROWTH & 0.0137 & 0.0160 & 0.401 \\
\hline LEVERAGE & -0.0225 & 0.0299 & 0.457 \\
\hline Observation & \multicolumn{3}{|c|}{150} \\
\hline$F(7,29)$ & \multicolumn{3}{|c|}{6.04} \\
\hline Prob $>$ F & \multicolumn{3}{|c|}{0.0002} \\
\hline R-squared & \multicolumn{3}{|c|}{0.0947} \\
\hline Root MSE & \multicolumn{3}{|c|}{0.20549} \\
\hline
\end{tabular}

This table illustrates the robustness result to solve heteroscedasticity and autocorrelation problems. The regression of restructured empirical model is written as below: 


$$
\begin{gathered}
G O P=0.4443+0.0001(D S O)+0.0004(D I O)-0.0004(D P O)-0.0004(C C C)-0.0239(S I Z E) \\
+0.0137(\text { GROWTH })-0.0225(L E V)+\mu
\end{gathered}
$$

Based on table 10 , the coefficient of DSO is 0.0001 , indicating that it is positively related with GOP. This implies that an increase of one day in the days sales outstanding is associated with an increase of $0.01 \%$ in GOP. However, the p-value of DSO (0.637) is greater than 5\% significance level. Thus, there is enough evidence to conclude that the relationship between DSO and GOP are statistically insignificant. This is in line with the research by Ponsian et. al. (2014) which reported a positive but insignificant relationship between DSO and GOP. Besides, the coefficient of DIO is 0.0004 and this indicates there is a positive relationship between the DIO and GOP. This result implies that there is an increase of $0.04 \%$ in GOP with a one-unit increase in days inventory outstanding. The p-value (0.012) is smaller than 0.05 significance level, which statistically proved that the relationship is significant. This finding is reinforced by previous studies by Mathuva (2010) and Gill, Biger and Mathur (2012). They found that there is a significant and positive association between DIO and GOP. The results also reveal that DPO has a negative relationship with GOP. The coefficient of DPO is -0.0004 , implying that an increase of one day in the days payables outstanding will lead to a decrease of 0.045 in GOP. This is because companies that accelerated their payment to suppliers may receive the benefit of a discount for early payment, thus increasing the company's profitability (Deloof, 2003). The p-value of DPO (0.026) is lower than 5\% significance level, indicating that the relationship is significant between DPO and GOP. This is in line with the research by Lazaridis and Tryfonidis (2006) which found that DPO is negative and significantly related to profitability.

The coefficient of the remaining independent variable, $\mathrm{CCC}$ is -0.0004 which represents a negative relationship with GOP. It is matched to the tenet that decrease in CCC is able to yield profit for company. However, the probability of CCC (0.062) is higher than 5\% significance level, indicating that the p-value are insignificantly different from zero. The relationship between CCC and GOP is insignificant. This is in line with the researches by Shin and Soenen (1998), Deloof (2003) and Samiloglu and Akgün (2016). They discovered that there is a negative and insignificant relationship between CCC and GOP. For the coefficient of control variable, firm size (-0.0239) implies a negative sign in the relationship to GOP. There will be a decline of $2.39 \%$ in GOP when there is one-unit increase in firm size. The probability of firm size ( $\mathrm{p}$-value $=0.557$ ) in this model is greater than $5 \%$ significance level, which implies that the relationship is not significant. This finding is consistent with the previous studies by Ponsian et al. (2014) and Thuvarakan (2013). They found that there is a negative and insigficant relationship between firm size and GOP.

In addition, the coefficient of sales growth (0.0137) apparently shows a positive relationship with GOP. The result indicates that an increase one-unit increase in the level of leverage leads to an increase of $1.37 \%$ in GOP. However, the p-value of sales growth $(0.401)$ in this model is greater than $5 \%$ significance level, implying that the result is not significant. This finding is supported by Deloof (2003), which found that an insignificant and positive relationship exists between sales growth and GOP. Other than that, the coefficient of leverage is -0.0225 , which shows negative relationship with GOP. This result implies that one-unit increase in leverage will cause GOP to decline by $2.25 \%$. However, the p-value is 0.457, depicting that leverage has an insignificant relationship with profitability since the p-value are higher than 0.05 significance level. This is in line with the research by Deloof (2003) and Ponsian et al. (2014). They showed that the relationship between the leverage and GOP is negative and insignifiacant. 
The R-squared value is 0.0947 , which implies that $9.47 \%$ of GOP (dependent variable) can be explained by DSO, DIO, DPO and CCC. According to the probability value of the F-test (0.0002), it depicts that the model is statistically significant at $5 \%$ as the p-value is lower than the 0.05 significance level. The null hypothesis is rejected and it proves that the working capital management variables from the model significantly explains profitability of construction firms in Malaysia.

\section{Discussion}

Based on the sample of this research, the results shows that the average days sales outstanding (DSO) is lengthy at 196 days. The random effect model indicates that DSO is positively associated with GOP with a coefficient of 0.000053 . The result after the robustness check also shows a positive relationship between DSO and GOP. This stipulates that an increase of one day in DSO will lead to an increase in GOP. This result is in line with previous studies by Deloof (2003), Garcia-Teruel and Solano (2007), Lazaridis and Tryfonidis (2006), Padachi (2006), Sharma and Kumar (2011) and Ponsian et. al. (2014). A reasonable explanation for the positive association between DSO and GOP is that when construction companies have lenient trade credit policy and offer customers with large volumes of sales in trade credit, it increases the companies' profitability because it allows customers to assess the product quality before paying. This would attract more customers as customers would like to confirm the product quality before paying the supplier. Therefore, higher investment in accounts receivable would lead to higher profitability. However, the result of this study suggests that this relationship is not significant and it coincides with the study from Sharma and Kumar (2011) and Ponsian et. al. (2014).

Next, the result presents that days inventory outstanding (DIO) has an average of 226, which is longer than the DSO. According to the random effect model, DIO is positively related to GOP with a coefficient of 0.0002 but the result is insignificant. This matches with the study by Thuvarakan (2013) whereby it is stated that there is an insignificant relationship between DIO and GOP. After the robustness check, the positive relationship between DIO and GOP becomes significant. This implies that the longer the DIO, the greater the profitability. In other words, investing more in inventories to maintain a higher level of inventories could lead to greater profitability. This is because having high level of inventories helps to reduce the risk of running out of stock and avoid the risk of price fluctuations. Both running out of stock and price fluctuations would badly impact a company's profitability. Thus, higher profitability can be achieved when inventories are maintained at a high level. This significant positive relationship between DIO and GOP is in line with the studies by Mathuva (2010) and Gill, Biger and Mathur (2010).

Most companies use trade credit as an important source of financing and trade credit plays a crucial role in working capital management. According to the result, the mean of days payables outstanding (DPO) is 335, which is the highest among all independent variables. The random effect model states that DPO has a negative relationship with GOP but it is insignificant. This result coincides with the study by Samiloglu and Akgün (2016). However, the negative association between DPO and GOP turned significant after conducting the robustness check and this result is consistent with the research by Lazaridis and Tryfonidis (2006). Based on the result, it suggests that the longer the DPO, the lower the firms' profitability. Basically, there are two possible explanations for this relationship. Firstly, companies making early payments to creditors are likely to have greater profitability because discounts are usually given to companies which make early payment within a period of time. Another reason is that companies with 
lower profitability tend to pay their creditors slower. Both of the explanations can be used to explain the negative association between DPO and GOP.

As mentioned by Tran, Abbott and Jin-Yap (2017), cash conversion cycle (CCC) is the time taken to recover cash from an outlay of cash. The results of this study denotes that the average CCC of listed construction companies in Malaysia is 93 days, which is the lowest among all independent variables. The random effect model suggests that there is a negative relationship between CCC and GOP. This implies that firms generate higher profit with lower CCC. In other words, firms with more aggressive working capital policy are associated with greater profitability. However, this result is insignificant. The result remains insignificant even after the robustness check is conducted. This result is similar to the researches by Shin and Soenen (1998), Deloof (2003) as well as Samiloglu and Akgün (2016), whereby it is claimed that there is an insignificant negative relationship between CCC and GOP.

\section{CONCLUSION}

Working capital management is crucial in maintaining the operation of a business. A successful business requires a steady flow of cash and efficient working capital management is required to further maximise the profitability. As stated by Tran, Abbott and Jin-Yap (2017), poor working capital management is one of the main factors that causes business failure. Therefore, working capital management is an important element in business operations and it is worthy for study. In this research, a sample of 30 construction firms listed on Bursa Malaysia was used to investigate the effect of working capital management on profitability over the period of 2015 to 2019. Based on the results of robustness check, it is found that DIO and GOP are significantly positively related while DPO and GOP are significantly negatively related. These results are reinforced by previous studies by Mathuva (2010) and Gill, Biger and Mathur (2010) which claimed that there is a significant positive relationship between DIO and GOP and Lazaridis and Tryfonidis (2006) which states that there is a significant negative relationship between DPO and GOP. Meanwhile, DSO is found be insignificantly positively associated with GOP while CCC is insignificantly negatively associated with GOP. The result between DIO and GOP coincides with the research by Ponsian et. al. (2014) and the result between CCC and GOP is in line with the studies by Shin and Soenen (1998), Deloof (2003) and Samiloglu and Akgün (2016).

The results implies that listed construction firms in Malaysia can maximise their profitability by maintaining higher level of inventory and paying off their creditors in a shorter time frame. In a nutshell, this study adds to the body of knowledge about the influence of working capital on profitability in Malaysian listed construction firms, as effective working capital management can have a substantial impact on the profitability and liquidity of a company. There are several limitations in this study. Firstly, the limitation of this study is that the nature of data collected from the annual report might be manipulated to what the firm wants to show in order to improve bonuses and boast stock prices to attract more share traders. The companies have a vested interest in highlighting and selling their business' financial achievements, with the aim to make their companies appear as an attractive investment to the shareholders. Therefore, the data collected might not be $100 \%$ representing the company's true condition. In addition, the sample period for this research is limited to 2015 to 2019. Further research is recommended to extend the period or include another time period such as the Global Financial Crisis period $(2007-2009)$ to compare the effect of working capital management on profitability during this time period with the normal period. Furthermore, the sample employed in this study is confined to the construction firms in Malaysia. 
Due to this reason, the result may not be fully representative of or comparable to companies in other industries or countries. Thus, it is highly recommended that further studies carry out research on various industries and expand the research area to other countries as well. The models and results of this study on the effect of working capital management on profitability in Malaysian listed construction firms could serve as a platform for future research in other industries as well as other countries.

\section{REFERENCES}

A.I.K Nai-Chiek \& Tee Peck-Ling. (2019). Working capital management and financial performance of Malaysian construction sector companies. Journal of Contemporary Issues and Thought, 9, 86-94.

Anser, R. \& Malik, Q. A. (2013). Cash Conversion Cyce and Firms' Profitability - A Study of Listed Manufacturing Companies of Pakistan. Journal of Business and Management, 8(2), 83-87.

Arbidane, I., \& Ignatjeva, S. (2013). The Relationship between Working Capital Management and Profitability: A Latvian Case. Global Review of accounting and Finance, 4(1). Retrieved from https://dx.doi.org/10.2139/ssrn.2128447

Aregbeyen, O. (2013). The effects of working capital management on the profitability of Nigerian manufacturing firms. Journal of Business Economics and Management, 14(3). Retrieved from http://dx.doi.org/10.3846/16111699.2011.651626

Arnold, G. (2008). Corporate Financial Management (4th ed.). Pearson Education Limited.

Baños-Caballero, S., García-Teruel, P. J., \& Martínez-Solano, P. (2012). How does working capital management affect the profitability of Spanish SMEs?. . Small business economics, 39(2), 517529.

Botoc, C., \& Anton, S. G. (2017). Is Profitability Driven By Working Capital Management? Evidence for High-Growth Firms from Emerging Europe. Journal of Business Economics and Management, 18(6). doi:10.3846/16111699.2017.1402362

Çakır, H. (2013). Nakit döngüsünün firma kãrliliğina etkisinin sektörel analizi. Yaşar Üniversitesi EDergisi, 8(30).

Chen, J. J. (2004). Determinants of capital structure of Chinese-listed companies. Journal of Business Research, 57(12). Retrieved from https://doi.org/10.1016/S0148-2963(03)00070-5

Deloof, M. (2003). Does Working Capital Management Affect Profitability of Belgian Firms?. Journal of Business Finance and Accounting, 30(3-4), 573-588.

Ding, S., Guariglia, A., \& Knight, J. . (2013). Investment and financing constraints in China: does working capital management make a difference?. Journal of Banking \& Finance, 37(5), 1490-1507.

Ebrahim Mansoori, \& Joriah Muhammad. (2012). The Effect of Working Capital Management on Firm's Profitability: Evidence from Singapore. Interdisciplinary Journal of Contemporary Research In Business, 4(5). Retrieved from https://ssrn.com/abstract=2185840

Eljelly, A. (2004). Liquidity-profitability tradeoff: an empirical investigation in an emerging market. International Journal of Commerce and Management, 14(2). Retrieved from http://dx.doi.org/10.1108/10569210480000179

Enqvist, J., Graham, M., \& Nikkinen, J. (2014). The impact of working capital management on firm profitability in different business cycles: Evidence from Finland. Research in International Business and Finance, 32,36-49.

Garcia-Teruel, P. J., \& Solano, P. M. (2007). Effects of Working Capital Management on SME Profitability. International Journal of Managerial Finance, 3(2), 164-177.

García-Teruel, P. J., \& Martínez-Solano, P. (2007). Effects of working capital management on SME profitability. International Journal of Managerial Finance, 3(2), 164-177. 
Gill, A., Biger, N., \& Mathur, N. (2011). The effect of capital structure on profitability: Evidence from the United States. International Journal of Management, 28(4), 3.

Gill, A., Biger, N., \& Mathur, N. (2010). The relationship between working capital management and profitability: Evidence from the United States. Business and Economics Journal, 10, 1-9.

Jensen, M. C. (1994). Self Interest, Altruism, Incentives, and Agency Theory. Journal of Applied Corporate Finance, 7(2). Retrieved from https://dx.doi.org/10.2139/ssrn.5566

Jensen, M.C., \& Meckling, W.H. (1976). Theory of the firm: managerial behavior, agency costs and ownership structure. Journal of Financial Economics, 3(4), 305-360.

Johnson, R., \& Soenen, L. (2003). Indicators of Successful Companies. European Management Journal, 21(3). Retrieved from http://dx.doi.org/10.1016/S0263-2373(03)00050-1

Kabuye, F., Kato, J., Akugizibwe, I., \& Bugambiro, N. (2019). Internal control systems, working capital management and financial performance of supermarkets. Cogent Business \& Management, 6(1). Retrieved from https://doi.org/10.1080/23311975.2019.1573524

Kwatiah, K. A., \& Asiamah, M. (2020). Working capital management and profitability of listed manufacturing firms in Ghana. International Journal of Productivity and Performance. Retrieved from https://doi.org/10.1108/IJPPM-02-2020-0043

Lazaridis, I., \& Tryfonidis, D. (2006). Relationship between working capital management and profitability of listed companies in the Athens stock exchange. Journal of Financial Management and Analysis, 19(1), 26-25.

Mahidin, M. U. (2019, March 7). Annual Economic Statistics 2018: Construction. Retrieved from Department of Statistics Malaysia Official Portal: https://dosm.gov.my/v1/index.php?r= column/cthemeByCat\&cat=321\&bul_id=dmdCbDFpaW96WkFmWjZZL0xma1hFUT09\&menu _id=OEY5SWtFSVVFVUpmUXEyaHppMVhEdz09

Mathuva, D. (2010). The influence of working capital management components on corporate profitability: A survey on Kenyan listed firms. Research Journal of Business Management, 4(1), 1-11.

Modigliani, F., \& Miller, M. H. (1963). Corporate income taxes and the cost of capital: A correction. American Economic Review, 53(3), 433-443.

Myers, S.C., \& Majluf, N.S. (1984). Corporate financing and investment decisions when firms have information that investors do not have. Journal of Financial Economics, 13(2), 187-221.

Napompech, K. (2012). Effects of Working Capital Management on the Profitability of Thai Listed Firms. International Journal of Trade, Economics and Finance, 3(3). doi: 10.7763/IJTEF.2012.V3.205

Oseifuah, E. K., \& Gyekye, A. (2016). Cash Conversion Cycle Theory and Corporate Profitability: evidence from non-financial firms listed on the Johannesburg stock exchange. Journal of Accounting and Management, 6(3). Retrieved from http://journals.univdanubius.ro/index.php/jam/article/view/3814

Oz, Y. \& Gungor, B. (2007) Çalışma Sermayesi Yönetiminin Firma Karlılı̆̆ Üzerine Etkisi:İmalat Sektörüne Yönelik Panel Veri Analizi. Ataturk Universitesi Sosyal Bilimler Enstitusu Dergisi, 10 (2), 319-332.

Padachi, K. (2006). Trends in working capital management and its impact on firms' performance: an analysis of Mauritian small manufacturing firms. International Review of Business Research Papers, 2(2), 45-48.

Ponsian, N., Chrispina, K., Tago, G., \& Mkiibi, H. (2014). The Effect of Working Capital Management on Profitability. Journal of Economics, Finance and Management Sciences, 2(6), 347-355.

Raheman, A., \& Nasr, M. (2007). Working Capital Management And Profitability-Case of Pakistani Firms. International Review of Business Research Papers, Vol. 3 (1), 279-300.

Rehman, A. (2006). Working Capital Management and Profitability: Case of Pakistani Firms. Pakistan: COMSATS Institute of Information Technology Islamabad. International working capital practices in the UK European Financial Management, 6(1), 69-84. 
Richards, V. D., \& Laughlin, E. J. (1980). A Cash Conversion Cycle Approach to Liquidity Analysis. Financial Management, 9(1). Retrieved from https://doi.org/10.2307/3665310

Samiloglu, F., \& Akgün, A. İ. (2016). The relationship between working capital management and profitability: Evidence from Turkey. Business and Economics Research Journal, 7(2), 1.

Sharma, A. K., \& Kumar, S. (2011). Effect of Working Capital Management on Firm Profitability: Empirical Evidence from India. Global Business Review, 12(1), 73-159.

Shin, H. H., \& Soenen, L. (1998). Efficiency of Working Capital and Corporate Profitability. Financial Practice and Education, 8(2), 37-45.

Thuvarakan, S. (2013). Impact of Working Capital Management on Profitability in UK Manufacturing Industry. SSRN Electronic Journal, 1-50.

Tran, H., Abbott, M., \& Jin-Yap, C. (2017). How does working capital management affect the profitability of Vietnamese small and medium sized enterprises?. Journal of Small Business and Enterprise Development, 24(1), 2-11. 